\title{
Research on the Goal and Related Problems of Accounting Higher Vocational Education in China
}

\author{
Hong Yu-xian \\ Jiangxi College Of Foreign Studies
}

\begin{abstract}
Higher vocational education is short for higher vocational and technical education, which is a new education type rose in the wave of our higher education. It belongs to the higher stage of vocational and technical education, also is an important part of higher education. To meet the social demand for accounting talents, accounting higher vocational education has made great progress, but the cultivation goal of accounting higher vocational education must have correct positioning. In the beginning, this paper analyzes the achievements and problems of our higher vocational accounting education since the reform and opening up; Then it proposes the countermeasures should be taken and introduces the relevant experience abroad; Finally, the conclusion is we should pay attention to and solve the existing problems when we fully confirm the achievement of our accounting higher vocational teaching.
\end{abstract}

Keywords-Higher vocational, accounting , teaching method

\section{INTRODUCTION}

In recent years, higher vocational education has cultivated a large number of urgently needed professionals for our modernization construction and made important contributions for effectively promoting the comprehensive development of our economy and society. Besides, it can be predicted that with the deepening of reform and opening up, our higher vocational education will play a greater role in the future. However, it should be noted that though the number of our higher vocational education has made considerable progress, it hasn't really become the mainstream schooling of ordinary higher school. The teaching materials of many higher vocational education are just like to compress the content of the subjects. Higher vocational education in China still despises the ability to do real work.
At present, our economy is in a period of high development, but high-level and high-quality talents is deficient. The technology and know-how talents in the production line is of more deficient. In recent years, although the government at all levels adjust and reform educational resources, take various measures to actively develop higher vocational education, the social prestige and the recognition of students and parents of higher vocational school are far from the ideal state.I think the main reason is deviation of the higher vocational teaching goal and the content. Higher vocational education should pay attention to both the highness and the profession. It's different from our traditional higher education and different from secondary vocational education. The main goal of ordinary higher education is to cultivate wide basic knowledge and adaptable "generalists"; While what the higher vocational education cultivates is professionals who can solve practical comprehensive problems on professional post..

This paper elaborates our accounting higher vocational education goal to carry on reform and exploration and proposes and analyzes new goal.

\section{THE REFORM EXPLORATION OF OUR ACCOUNTING HIGHER VOCATIONAL EDUCATION GOAL}

\section{A. 1. New positioning of accounting higher vocational education goal}

In recent years, the education concept of "generalist" in western countries has led to a discussion about the talent cultivation goal in our country. For example: US AECC stated in \#1 communique "The purpose of accounting education is not to train students to be an professional upon graduation, but to train them to have the qualities to become a professional." Regarding to the disparities between the "generalist" education of the western countries and the "specialist" education in our 
country, the accounting educators also appeal Chinese accounting education should take the education road of "generalist". But most of them think according to our national conditions, the Chinese present accounting education is more suitable for the "generalist and specialist" road.

\section{B. The appropriateness of the newly positioned accounting higher vocational education goal compared with the old goal}

The newly positioned accounting higher vocational goal is to emphasize the cultivation of vocational and technical training of the students rather than professional skills. The accounting expertise is specific, such as billing according to certain standards, making report reforms according to certain formats, adding up finance and analyzing data according to certain requirements, while accounting specialized skills are the abilities to engage in accounting a wider environment .For example: the ability to formulate accounting system in different enterprise environment and economic system, the ability to formulate accounting cycle program under manual or computer environment and the ability to select accounting policy in different tax systems.

\section{MAIN PROBLEMS EXISTING IN OUR ACCOUNTING VOCATIONAL HIGHER VOCATIONAL EDUCATION}

There are still some problems in the existing higher vocational accounting curriculum system. Mainly in the following aspects:

Despise technology education course. Accounting higher vocational should pay attention to the number and categories of the specialty courses to enhance students' adaptability. From the investigation ,besides training course, the schools investigated only open about 6 accounting specialty courses.

Curriculum system involves a narrow knowledge scope and students' knowledge structure is unreasonable. Such curriculum causes the graduates don't know how to handle the enterprise practical problems when they go to work and extends the adaptability to the actual work.

Attach importance to knowledge imparting and despise ability cultivation. It shows in curriculum system that it mainly emphasizes knowledge imparting and ignores the curriculum which is helpful to cultivate students' writing skills, language skills, practical operation skills and comprehensively analyzing ability. For instance, writing, academic paper, case analysis and stimulation experiment.etc.

\section{SOLUTIONS TO OUR ACCOUNTING VOCATIONAL}

\section{EDUCATION}

Considering curriculum setting is narrow and unreasonable knowledge structure of the students, it's suggested to open Chinese tax system, management and international trading. etc.

In order to improve students' writing skills, practical operation skills and comprehensively analyzing ability, it need to open courses such as writing, academic paper, case analysis and stimulation experiment and so on.

Properly reduce the public basic course or class hours. Vocational students general have weak basic cultural course, such as poor maths and English. Students don't master well even with too many basic courses or class hours .Since the author positions the goal of accounting vocational to be "cultivate junior accounting talents", which don't need to master a lot of higher maths knowledge or English.

To expand student's job opportunities, it can open some optional courses, such as administrative and public accounting , enterprises with foreign investment accounting, budget accounting and so on.

\section{CONCLUSION}

We should pay attention to and solve the problems when we fully affirm the achievement made by our accounting higher vocational education. As a result, we can refer to the experience of the developed countries, actively explore the education goal of the higher vocational accounting suitable for our national condition. In order to achieve higher vocational accounting goal, we should compile special accounting teaching materials, establish reasonable curriculum setting system and actively carry on teaching reform. In this way can we not only improve students' practical ability and working ability but also establish a more reasonable accounting higher vocational accounting teaching system with more outstanding practical characteristics . This paper summarizes the reform policy of our accounting education and the problems after the reform. It makes some suggestions to the problems, mainly the opening of the 
curriculum and the teaching activity in class will have an impact on students' interest.

\section{REFERENCES}

[1] [1]Dechow, Patricia M., and D. J. Skinner. "2000, Earnings management: Reconciling the views of accounting academics, practitioners, and regulators, Accounting Horizons." Accounting Review 14(2000).

[2] [2] Feltham G A, Ohlson J A. Valuation and Clean Surplus Accounting for Operating and Financial Activities $\dagger[\mathrm{J}]$. Contemporary Accounting Research, 2010, 11(2):689-731.

[3] [3] Feltham G A, Ohlson J A. Valuation and Clean Surplus Accounting for Operating and Financial Activities $\dagger[\mathrm{J}]$. Contemporary Accounting Research, 2010, 11(2):689-731.

[4] [4] Chua, Wai Fong. "Radical Developments in Accounting Thought." Accounting Review 61.4(1986):601-632.

[5] [5] Duval S, Tweedie R. A Nonparametric "Trim and Fill” Method of Accounting for Publication Bias in Meta-Analysis[J]. Journal of the American Statistical Association, 2000, 95(449):89-98.
[6] [6]Cowie C C, Rust K F, Ford E S, et al. Full Accounting of Diabetes and Pre-Diabetes in the U.S. Population in 1988-1994 and 2005-2006[J]. Diabetes Care, 2009, 32(2):287-294.

[7] [7]INDJEJIKIAN, Raffi J. Accounting Information, Disclosure, and the Cost of Capital[J]. Journal of Accounting Research, 2007, 45(2):385-420.

[8] [8] Krasney, Melvin A. "Cost Accounting: A Managerial Emphasis." Accounting Review 4(1978):889-890.

[9] [9]Duffie, Darrell, and D. Lo. "The Term Structure of Credit Spreads with Incomplete Accounting Information." Econometrica 69.3(2001):633-664.

[10] [10] Estan C, Varghese G. New directions in traffic measurement and accounting: Focusing on the elephants, ignoring the mice $[\mathrm{J}]$. Acm Transactions on Computer Systems, 2003, 21(3):270--313.

[11] [11]Otley, David T. The contingency theory of management accounting: achievement and prognosis. Readings in Accounting for Management Control. Springer US, 1980:83-106.

[12] [12]Cowie C C, Rust K F, Ford E S, et al. Full Accounting of Diabetes and Pre-Diabetes in the U.S. Population in 1988-1994 and 2005-2006[J]. Diabetes Care, 2009, 32(2):: 287-294. 